2019-12-01

\title{
Recycled electronic plastic and marine
}

\section{litter}

\author{
Shaw, EJ
}

http://hdl.handle.net/10026.1/14832

10.1016/j.scitotenv.2019.133644

Science of the Total Environment

Elsevier

All content in PEARL is protected by copyright law. Author manuscripts are made available in accordance with publisher policies. Please cite only the published version using the details provided on the item record or document. In the absence of an open licence (e.g. Creative Commons), permissions for further reuse of content should be sought from the publisher or author. 


\section{Recycled electronic plastic and marine litter}

2 Emma J. Shaw, Andrew Turner*

3

4 School of Geography, Earth and Environmental Sciences,

5 University of Plymouth

$6 \quad$ Drake Circus

7 Plymouth PL4 8AA, UK

8 *aturner@plymouth.ac.uk

9

10 Accepted: 26 July 2019

11 https://doi.org/10.1016/j.scitotenv.2019.133644 
Black consumer plastics are often contaminated with hazardous chemicals because of technological constraints on sorting dark plastic during recycling of municipal waste coupled with the convenience of waste electrical and electronic equipment (WEEE) as a secondary source of black plastic. In this study, samples of beached plastic litter $(n=524)$ from southwest England were categorised according to origin, appearance and colour (black versus non-black) before being analysed by $\mathrm{x}$-ray fluorescence (XRF) spectrometry for elements that are characteristic of EEE. The small number of items of WEEE retrieved $(n=36)$ were largely restricted to wiring insulation and constructed of leadstabilised polyvinyl chloride (PVC). Amongst the remaining samples, $\mathrm{Br}, \mathrm{Cd}, \mathrm{Cr}$ and $\mathrm{Pb}$ were commonly detected in all categories of black plastics $(n=264)$ with maximum concentrations of 43,400 mg kg${ }^{-1}, 2080 \mathrm{mg} \mathrm{kg}^{-1}, 662 \mathrm{mg} \mathrm{kg}^{-1}$ and 23,800 $\mathrm{mg} \mathrm{kg}^{-1}$, respectively. Moreover, concentrations of $\mathrm{Br}$ were significantly correlated with concentrations of the flame retardant synergist, $\mathrm{Sb}(n=22)$, and 35 samples were potentially non-compliant with regard to limits defined by the Restriction of Hazardous Substances Directive. For plastics of other colours ( $n=224), \mathrm{Br}$ and $\mathrm{Pb}$ were detected in fewer samples and $\mathrm{Br}$ was co-associated with $\mathrm{Sb}$ in only two cases, with occasional high concentrations $\mathrm{Cd}, \mathrm{Cr}$ and $\mathrm{Pb}$ largely attributed to the historical use of cadmium sulphide and lead chromate pigments. An avian physiologically-based extraction test applied to selected samples cut to $\mathrm{mm}$-dimensions revealed bioaccessibilities ranging from $<0.1 \%$ for $\mathrm{Cr}$ in a green fragment to about $2.4 \%$ (or about $580 \mathrm{mg} \mathrm{kg}^{-1}$ ) for $\mathrm{Pb}$ in black PVC. The recycling of WEEE into consumer, industrial and marine (e.g. fishing) plastics that are mainly coloured black appears to be an important vehicle for the introduction of hazardous chemicals into the environment and a source of their exposure to wildlife.

Keywords: electrical and electronic; marine plastic; bromine; heavy metals; recycling; exposure

\section{Introduction}

From both a human health and environmental perspective, one of the major concerns associated with plastics, and in particular those available to the consumer, is the presence and potential mobility of harmful chemicals (Lithner et al., 2011). Residues may remain in the polymeric matrix as polymerisation catalysts, unreacted monomers or impurities, while other chemicals are added intentionally to improve performance, functionality and ageing properties and include fillers, 
plasticisers, pigments for colour, flame retardants, antistatic agents, lubricants, biocides and heat and UV stabilisers (Gallo et al., 2018; Hahladakis et al., 2018).

Various international regulations have been introduced to restrict the amount or mobility of certain hazardous chemicals in consumer plastics. For example, the European Packaging and Packaging Waste Regulations stipulate that the aggregate concentrations of the heavy metals, $\mathrm{Cd}, \mathrm{Hg}, \mathrm{Pb}$ and hexavalent $\mathrm{Cr}$, should not exceed $100 \mathrm{mg} \mathrm{kg}^{-1}$ in plastic packaging or packaging components except for pallets and crates that are in a controlled distribution and reuse system (European Parliament and Council of the EU, 1994; BIS, 2015). The same metals, plus certain brominated flame retardants (polybrominated biphenyls, PBB, and polybrominated diphenyl ethers, PBDE) are encompassed by the Restriction on Hazardous Substances (RoHS) Directive that deals with electrical and electronic equipment (EEE), including EEE plastic (European Parliament and Council, 2003; BIS, 2011). Effective since 2006, and forming the basis of similar regulations worldwide (Ilankoon et al., 2018), this Directive stipulates that hazardous chemicals should be avoided and that concentrations are limited in any homogeneous component of EEE to concentrations of $1000 \mathrm{mg} \mathrm{kg}^{-1}$ or, for $\mathrm{Cd}$, to $100 \mathrm{mg} \mathrm{kg}^{-1}$.

While PBB and PBDE (as flame retardants) and compounds of $\mathrm{Pb}$ and $\mathrm{Cd}$ (as, for example, heat stabilisers in PVC) have been used directly in historical EEE plastics, restricted chemicals used in other (non-plastic) components of EEE, like soldered joints, corrosion protectors and switches, are able to contaminate any plastic that is recovered (Wäger et al., 2012). Consequently, plastic recycled from waste EEE (WEEE), unless properly screened and sorted, is a source of hazardous chemical exposure in new goods, including consumer products (Turner and Filella, 2017; Cao et al., 2019). This problem is particularly acute in black plastics because conventional and widely adopted nearinfrared sensors used to discriminate municipal waste plastic by resin code (polymer type) for recycling are unable to detect a sufficient spectral signal from this colour (Rozenstein et al., 2017). With black being a common and popular choice for EEE plastic housings, WEEE appears to be a convenient source of plastic recyclate for new black goods (Turner, 2018a).

The marine environment is a significant recipient of vast quantities of contemporary and historical plastic from a multitude of land-based and offshore sources. Much of this plastic is likely to have been manufactured or recycled before regulations on hazardous chemicals were in place but relatively little attention has been paid to additives and residues in marine waste and to whether material is compliant or poses a threat to wildlife. A recent review by Hermabessiere et al. (2017) highlighted the dearth of information in this respect but suggested that brominated flame retardants, phthalate plasticisers, nonylphenols and bisphenol A are of greatest concern. However, elemental measurements of marine plastic suggest that heavy metals are also a potential 
ecotoxicological risk (Turner, 2016; Massos and Turner, 2017), with chemical signatures bearing similarities with WEEE plastic in many cases (Turner, 2018a).

In the present study, plastic samples, including WEEE material, are collected from beaches of south west England and analysed in the context of the RoHS Directive in order to evaluate the presence and origin of hazardous additives (and as conceptualised in Figure 1). Specifically, material is tested by $\mathrm{x}$-ray fluorescence (XRF) spectrometry for $\mathrm{Cd}, \mathrm{Pb}, \mathrm{Hg}$, total $\mathrm{Cr}$ as a proxy for $\mathrm{Cr}(\mathrm{VI})$, and elemental $\mathrm{Br}$ as a proxy for restricted brominated flame retardants, with compliance limits equal to those given in the RoHS Directive and stated above with the exception of $\mathrm{Br}$ (set at $700 \mathrm{mg} \mathrm{kg}^{-1}$, a representative concentration of $\mathrm{Br}$ in $1000 \mathrm{mg} \mathrm{kg}^{-1}$ of restricted brominated compounds). Antimony is also analysed because of its co-association with many halogenated flame retardants as a flame quenching synergist and $\mathrm{Cl}$ is analysed in order to discriminate polyvinyl chloride (PVC) from other types of polymer. Samples are further categorised according to visual characteristics (e.g. primary versus secondary plastics), and samples coloured black are compared with samples of other colours to test the hypothesis that black plastics are more likely to be derived from recycled WEEE because of difficulties in sorting and recycling this colour from the municipal waste stream. An avian physiologically-based extraction test (PBET) is also applied to selected samples that had been grated to $\mathrm{mm}$-dimensions in order to evaluate elemental bioaccessibility to seabirds that incidentally or deliberately ingest microplastics. 


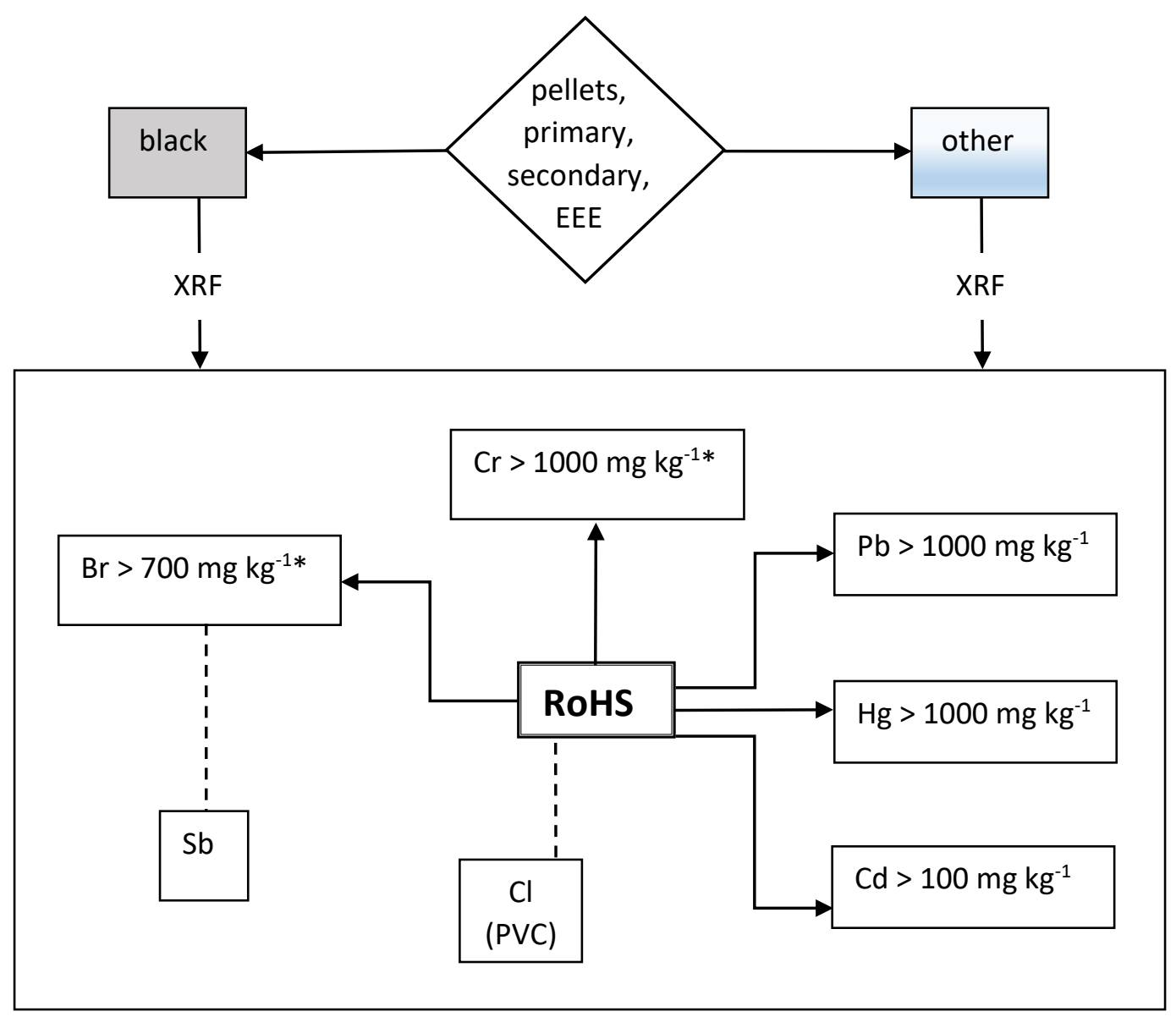

Figure 1: Flowchart showing the categorisation of marine plastics and the elements analysed in the present study, with RoHS-compliance limits indicated where applicable (asterisks denote potential compliance limits).

\section{Methods}

\subsection{Sampling}

Samples of marine plastic (excluding rubbers) visible by eye were collected by hand during late 2018 and early 2019 from 50 m sections of the strandlines of five southwest- or northwest-facing sandy beaches in south west England; namely, Thurlestone (50.26436, -3.86164), Sharrow (50.34753, 4.25983), Tregonhawke (50.34043, -4.24220), Marazion (50.12380, -5.47642) and Crantock (50.40799, -5.12553). In addition, plastic samples were retrieved from the south east-facing small rocky-sandy cove of Picklecombe $(50.34272,-4.17855)$ in Plymouth Sound, a more sheltered embayment supporting a variety of industries and shipping activities.

In the laboratory, samples were rinsed under tap water to remove traces of surficial sea salts and air-dried for 48 hours before being categorised as pellets (nurdles and water treatment bio-beads of 
$<5 \mathrm{~mm}$ in diameter), primary plastics (distinct objects), secondary fragments whose origin could be identified, secondary fragments of unknown origin, and objects and fragments of electrical and electronic equipment. Within each category, samples were further divided by colour type into plastics that were black (including charcoal and dark grey) and that were non-black.

\subsection{XRF analysis}

About 500 samples were characterised for a range of elements (but focussing on $\mathrm{Cl}, \mathrm{Br}, \mathrm{Cd}, \mathrm{Cr}, \mathrm{Hg}$, $\mathrm{Pb}, \mathrm{Sb})$ by field portable XRF spectrometry, with at least 30 selected from each category and colour type where possible. Samples were placed in an accessory test stand with the flattest surface over the detector window of a battery-powered Niton XL3t 950 He GOLDD+ XRF Samples too big to fit in the stand were cut to an appropriate size with scissors or a knife and any metal components embedded in plastic (e.g. electrical wires) were removed with pliers. The XRF was operated remotely in a plastics mode with thickness correction and after having measured sample thickness with digital callipers, for successive counting periods of $25 \mathrm{~s}$ at $50 \mathrm{kV}$ and $40 \mu \mathrm{A}$ and $15 \mathrm{~s}$ at $20 \mathrm{kV}$ and $100 \mu \mathrm{A}$.

For quality assurance purposes, two reference polyethylene discs were analysed after every 15 samples; specifically, disc PE-071-N (PN 180-554) contained $\mathrm{Br}, \mathrm{Cd}, \mathrm{Cr}, \mathrm{Hg}$ and Pb at concentrations similar to corresponding limits defined by the RoHS, and disc T-18 (PN 180-619) contained Cd, Cr, Hg, $\mathrm{Pb}$ and $\mathrm{Sb}$ at concentrations $<200 \mathrm{mg} \mathrm{kg}^{-1}$. Concentrations returned by the XRF were always within $10 \%$ of reference values with the exception of Sb (up to $16 \%$ ) and, overall, replicate readings revealed precisions of better than $90 \%$. Median measurement detections limits, based on three

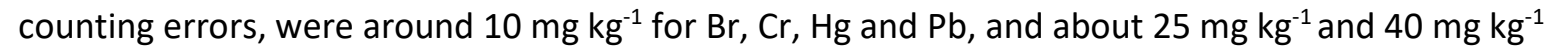
for $\mathrm{Cd}$ and $\mathrm{Sb}$, respectively.

\subsection{Avian PBET}

A physiologically-based extraction test (PBET) based on the digestive conditions encountered in the gizzard-proventriculus of the northern fulmar (Fulmarus glacialis) was employed to evaluate the bioaccessibility of hazardous elements in selected plastic samples (Turner, 2018b). Thus, eight samples from different categories and of both colour type were cut to 1-2 $\mathrm{mm}$ pieces using a stainless steel grater and $100 \mathrm{mg}$ of each were weighed into individual, screw-capped polypropylene centrifuge tubes. Digestive fluid was prepared in a $500 \mathrm{~mL}$ volumetric flask by dissolving $5 \mathrm{~g}$ of pepsin (lyophilised powder from porcine gastric mucosa; Sigma-Aldrich) in a solution of $0.1 \mathrm{M} \mathrm{NaCl}$ whose $\mathrm{pH}$ was adjusted to 2.5 by dropwise addition of $1 \mathrm{M} \mathrm{HCl}$. Aliquots of $40 \mathrm{~mL}$ were added to each centrifuge tube, plus a tube without solids as a control, and the contents incubated laterally in a Fisher Scientific Isotemp SWB27 water bath set at $40^{\circ} \mathrm{C}$ and $100 \mathrm{rpm}$. After $120 \mathrm{~h}, 1 \mathrm{~mL}$ of fluid 
from each reactor was pipetted into a new centrifuge tube and diluted to $5 \mathrm{~mL}$ with $2 \% \mathrm{HNO}_{3}$ and stored under refrigeration awaiting analysis.

Extracts were analysed in triplicate for ${ }^{81} \mathrm{Br},{ }^{111} \mathrm{Cd},{ }^{52} \mathrm{Cr},{ }^{208} \mathrm{~Pb}$ and ${ }^{121} \mathrm{Sb}$ by collision cell-inductively coupled plasma-mass spectrometry (ICP-MS) using a Thermo-Scientific iCAP RQ with a concentric glass nebuliser and conical spray chamber. The instrument was calibrated externally using five mixed standards (in the range 0 to $40 \mu \mathrm{g} \mathrm{L}^{-1}$ ) of each element prepared in $2 \% \mathrm{HNO}_{3}$, and internal calibration was achieved by the addition of $50 \mathrm{\mu g} \mathrm{L}^{-1}$ of both ${ }^{115} \mathrm{In}$ and ${ }^{193} \mathrm{Ir}$ to all standards and samples. Radio frequency power was $1450 \mathrm{~W}$ and auxiliary, coolant, nebuliser and collision cell gas flows rates were $0.80 \mathrm{~L} \mathrm{Ar} \mathrm{min}^{-1}, 14 \mathrm{~L} \mathrm{Ar} \mathrm{min}^{-1}, 1.07 \mathrm{~L} \mathrm{Ar} \mathrm{min}^{-1}$ and $4.288 \mathrm{~mL} 7 \% \mathrm{H}_{2}$ in He $\mathrm{min}^{-1}$, respectively; data were acquired over a dwell period of $10 \mathrm{~ms}$ and with 50 sweeps per reading. Analytical precision between replicates was generally better than $90 \%$ and limits of detection, based on three standard deviations arising from blank measurements, ranged from about $0.01 \mu \mathrm{g} \mathrm{L}^{-1}$ for $\mathrm{Cd}$ to $0.3 \mu \mathrm{g} \mathrm{L}^{-1}$ for $\mathrm{Br}$.

\section{Results}

\subsection{Visual and physical characteristics}

Table 1 shows the number of samples from each category that were analysed by XRF, along with the number of samples that were constructed of PVC based on the intrinsic chlorine signal returned by the instrument $\left(>150,000 \mathrm{mg} \mathrm{kg}^{-1}\right)$. Note that other polymers were not identified, largely because of difficulties in obtaining infrared or Raman spectra for black plastics, but previous studies of beached primary and secondary plastics (including pellets) of other colours from these environments indicate a dominance of polyethylene and polypropylene (Massos and Turner, 2017). Note also that the numbers in Table 1 do not reflect the relative abundance of each category or colour but were aimed at providing a representative sample number of each type for comparative purposes. Significantly, while the majority of bio-beads and electronic plastics were black, this colour comprised between about $5 \%$ and $10 \%$ of other sample types on a number basis.

There was a limited number of electrical and electronic samples along the beach strandlines $(n=$ 36), with the majority of such items retrieved from two locations and comprising offcuts of (mainly) black, PVC-based wire and cable insulation whose electrical wires were still intact at the time of sampling. Remaining samples from this category were non-PVC-based casings (or casing parts) from small electronic communication equipment, including the front frames of a mobile phone and a radio. None of the 137 pellet samples retrieved were constructed of PVC, and while bio-beads used 
in water treatment were mainly black, pre-production pellets were a variety of colours but mainly white to off-white or translucent.

Black primary plastics ( $n=63$ ) included lids, combs, buttons, bottle tops, wire ties, toys and tubing but no items in this category were constructed of PVC; primary plastics of other colours $(n=30)$ included, additionally, lolly sticks, pens, cigarette lighters, bottle stoppers, golf tees and gun cartridges, with a single item (an orange bottle cap) constructed of PVC. Secondary plastics that were identifiable $(n=109)$ included fragments from cutlery, bottles, clothes hangers, handles, straps, fencing, fishing ropes and plant pots of different colours (including black) and four PVC-based items; secondary fragments of different colours that were not recognisable $(n=149)$ were generally smaller and more rounded and either flat or curved, and included a greater proportion of PVC-based items $(n=8)$.

201

Table 1: The number of beached plastic samples, by category and colour, analysed by XRF. Numbers in parentheses denote samples of PVC-construction.

\begin{tabular}{lccc}
\hline & black & other colours & total \\
\hline pellets & 39 & 98 & 137 \\
primary & 63 & $30(1)$ & $93(1)$ \\
secondary known & $72(3)$ & $37(1)$ & $109(4)$ \\
secondary unknown & $90(3)$ & $59(5)$ & $149(8)$ \\
EEE & $26(20)$ & $10(2)$ & $36(22)$ \\
total & $290(26)$ & $234(9)$ & $524(35)$ \\
\hline
\end{tabular}

\subsection{Chemical characteristics}

The number of cases in which $\mathrm{Br}, \mathrm{Cd}, \mathrm{Cr}, \mathrm{Hg}, \mathrm{Pb}$ and $\mathrm{Sb}$ were detected, along with summary statistics defining their concentrations, are shown for each plastic category and both colour type in Tables 2 and 3. Bromine, $\mathrm{Pb}$ and $\mathrm{Sb}$ were detected more frequently, on a number and percentage (relative to total) basis, in black plastics than in other coloured plastic in each category. Overall, respective detection in black plastic and other plastic was about $40 \%$ and $16 \%$ for $\mathrm{Br}, 34 \%$ and $15 \%$ for $\mathrm{Pb}$, and $13 \%$ and $2 \%$ for $\mathrm{Sb}$. Detection of $\mathrm{Cd}$ and $\mathrm{Cr}$ was more evenly distributed between categories and colour type, although the former was more abundant among secondary plastics, and Hg was only detected in one sample (a black radio cover).

213 Concentrations are highly variable and non-normally distributed within each category and for both 214 colour types of plastic, and in particular among black plastics where concentrations of $\mathrm{Pb}$ span five orders of magnitude and concentrations of $\mathrm{Br}$ and $\mathrm{Sb}$ span three orders of magnitude. With respect to the RoHS limits shown in Figure 1, non-compliance (or potential non-compliance), also indicated 
in Tables 2 and 3 and exemplified illustratively in Figure 2, occurs in 46 cases for black samples (and mainly for $\mathrm{Br}, \mathrm{Cd}$ and $\mathrm{Pb}$ ) and in 26 cases for plastics of other colours (and largely for $\mathrm{Cd}$ and $\mathrm{Pb}$ ), with only one sample potentially non-compliant with respect to two elements ( $\mathrm{Cd}$ and $\mathrm{Cr}$ in a green, secondary unknown fragment).

221

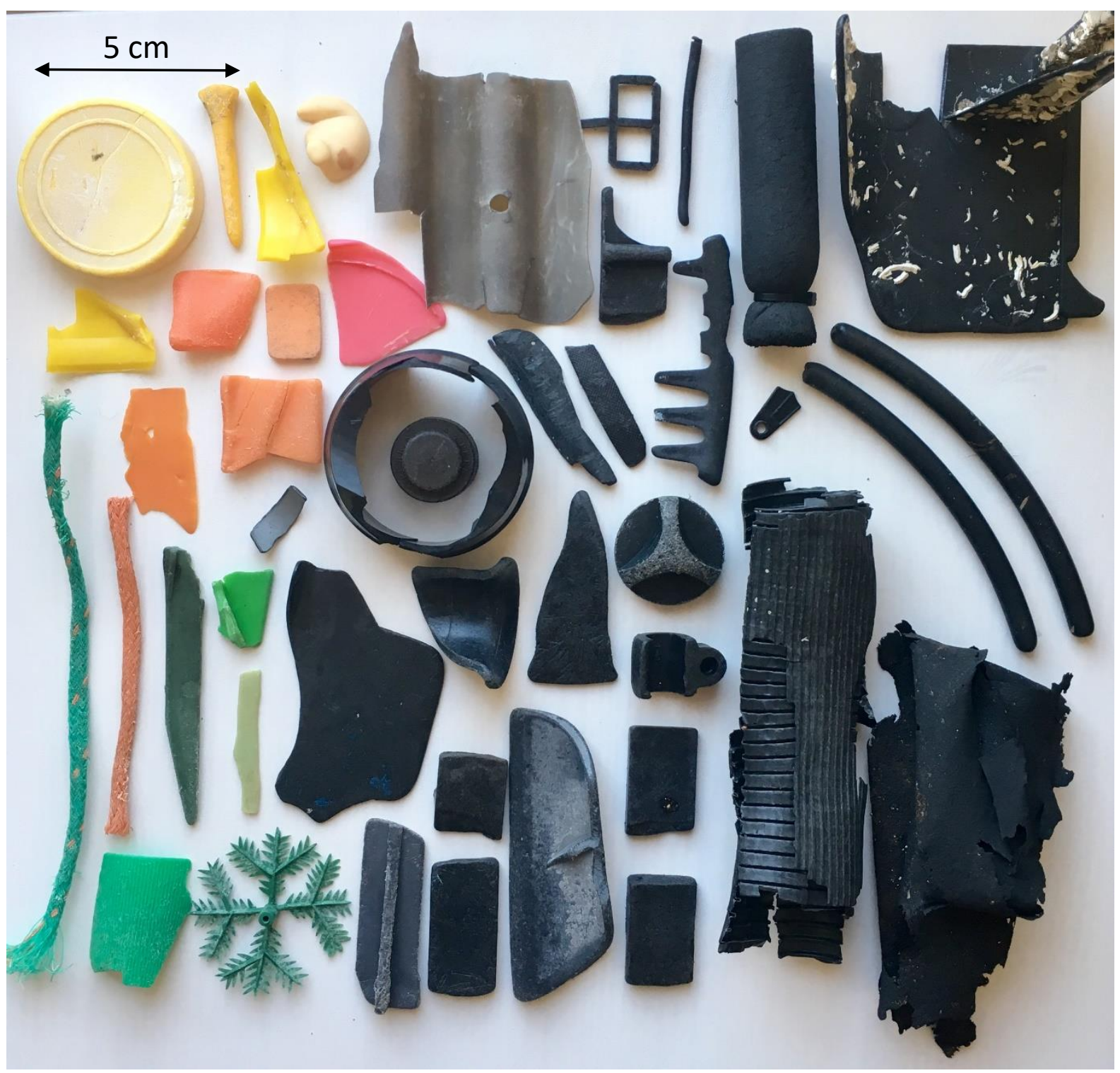

223 Figure 2: Examples of beached plastics from south west England that were non-compliant or

224 potentially non-compliant with respect to RoHS regulations.

Table 2: Number of cases in which hazardous elements were detected and summary statistics for their concentrations in the different categories of beached black plastics. Note that all 
concentrations are in $\mathrm{mg} \mathrm{kg}^{-1}$ and that $n>$ RoHS refers to the number of cases in which concentrations exceed corresponding RoHS limits.

\begin{tabular}{|c|c|c|c|c|c|c|c|}
\hline & & $\mathrm{Br}$ & $\mathrm{Cd}$ & $\mathrm{Cr}$ & $\mathrm{Hg}$ & $\mathrm{Pb}$ & $\mathrm{Sb}$ \\
\hline \multirow[t]{6}{*}{ pellets $(n=39)$} & $n$ & 24 & 5 & 19 & 0 & 16 & 6 \\
\hline & mean & 272 & 105 & 73.8 & & 69.2 & 606 \\
\hline & median & 20.9 & 46.5 & 47.4 & & 23.4 & 139 \\
\hline & $\min$ & 4.4 & 35.1 & 17.4 & & 7.9 & 74.0 \\
\hline & $\max$ & 5020 & 321 & 249 & & 494 & 2810 \\
\hline & $n>$ RoHS & 1 & 1 & 0 & 0 & 0 & \\
\hline \multirow[t]{6}{*}{ primary $(n=63)$} & $n$ & 20 & 5 & 21 & 0 & 17 & 7 \\
\hline & mean & 346 & 794 & 34.7 & & 48.7 & 478 \\
\hline & median & 31.5 & 461 & 29.0 & & 33.0 & 359 \\
\hline & $\min$ & 3.5 & 21.7 & 17.3 & & 6.6 & 37.3 \\
\hline & $\max$ & 1840 & 2080 & 64.6 & & 159 & 884 \\
\hline & $n>$ RoHS & 4 & 5 & 0 & 0 & 0 & \\
\hline \multirow[t]{6}{*}{ secondary known $(n=72)$} & $n$ & 20 & 5 & 23 & 0 & 22 & 10 \\
\hline & mean & 377 & 598 & 38.8 & & 863 & 540 \\
\hline & median & 26.2 & 534 & 30.7 & & 42.6 & 249 \\
\hline & $\min$ & 3.8 & 24.9 & 19.3 & & 4.3 & 210 \\
\hline & $\max$ & 4100 & 1750 & 95.3 & & 9490 & 2810 \\
\hline & $n>$ RoHS & 3 & 2 & 0 & 0 & 2 & \\
\hline \multirow[t]{6}{*}{ secondary unknown $(n=90)$} & $n$ & 29 & 23 & 34 & 0 & 30 & 8 \\
\hline & mean & 2190 & 261 & 66.8 & & 943 & 2320 \\
\hline & median & 28.7 & 212 & 34.4 & & 79.0 & 74.9 \\
\hline & $\min$ & 4.0 & 29.0 & 17.9 & & 8.3 & 33.1 \\
\hline & $\max$ & 43,400 & 1080 & 662 & & 23,800 & 12,500 \\
\hline & $n>$ RoHS & 2 & 14 & 0 & 0 & 1 & \\
\hline \multirow[t]{6}{*}{$\operatorname{EEE}(n=26)$} & $n$ & 13 & 0 & 1 & 1 & 14 & 6 \\
\hline & mean & 217 & & 22.0 & 8.6 & 35,600 & 20,400 \\
\hline & median & 192 & & & & 38,100 & 23,900 \\
\hline & $\min$ & 29.9 & & & & 58.7 & 189 \\
\hline & $\max$ & 516 & & & & 116,000 & 29,800 \\
\hline & $n>$ RoHS & 0 & 0 & 0 & 0 & 11 & \\
\hline
\end{tabular}

231 Table 3: Number of cases in which hazardous elements were detected and summary statistics for

232 their concentrations in the different categories of beached plastics of colours other than black. Note

233 that all concentrations are in $\mathrm{mg} \mathrm{kg}^{-1}$ and that $n>$ RoHS refers to the number of cases in which

234 concentrations exceed corresponding RoHS limits. 


\begin{tabular}{|c|c|c|c|c|c|c|c|}
\hline & & $\mathrm{Br}$ & $\mathrm{Cd}$ & $\mathrm{Cr}$ & $\mathrm{Hg}$ & $\mathrm{Pb}$ & $\mathrm{Sb}$ \\
\hline \multirow[t]{6}{*}{ pellets $(n=98)$} & $n$ & 8 & 5 & 55 & 0 & 9 & 1 \\
\hline & mean & 6.3 & 74.1 & 30.3 & & 29.7 & 46.4 \\
\hline & median & 6.3 & 51.7 & 27.9 & & 13.2 & \\
\hline & $\min$ & 3.3 & 32.5 & 21.1 & & 4.4 & \\
\hline & $\max$ & 10.8 & 144 & 71.4 & & 76.4 & \\
\hline & $n>\mathrm{RoHS}$ & 0 & 2 & 0 & 0 & 0 & \\
\hline \multirow[t]{6}{*}{ primary $(n=30)$} & $n$ & 4 & 3 & 10 & 0 & 3 & 1 \\
\hline & mean & 61.5 & 1780 & 180 & & 1430 & 1140 \\
\hline & median & 29.3 & 587 & 28.7 & & 634 & \\
\hline & $\min$ & 9.5 & 55.8 & 19.2 & & 28.7 & \\
\hline & $\max$ & 178 & 4680 & 1270.0 & & 3620 & \\
\hline & $n>$ RoHS & 0 & 2 & 1 & 0 & 1 & \\
\hline \multirow[t]{6}{*}{ secondary known $(n=37)$} & $n$ & 14 & 3 & 11 & 0 & 9 & 3 \\
\hline & mean & 109 & 379 & 158 & & 461 & 498 \\
\hline & median & 22.0 & 376 & 40.2 & & 159 & 74 \\
\hline & $\min$ & 4.7 & 29.6 & 20.5 & & 5.8 & 67.0 \\
\hline & $\max$ & 1070 & 731 & 598 & & 1840 & 1350 \\
\hline & $n>$ RoHS & 1 & 3 & 0 & 0 & 3 & \\
\hline \multirow[t]{6}{*}{ secondary unknown $(n=59)$} & $n$ & 11 & 9 & 15 & 0 & 10 & 0 \\
\hline & mean & 45.9 & 905 & 363 & & 1620 & \\
\hline & median & 19.6 & 293 & 44.2 & & 808 & \\
\hline & $\min$ & 3.3 & 21.8 & 17.5 & & 6.6 & \\
\hline & $\max$ & 210 & 3130 & 2910 & & 8950 & \\
\hline & $n>\mathrm{RoHS}$ & 0 & 7 & 1 & 0 & 4 & \\
\hline \multirow[t]{6}{*}{$\operatorname{EEE}(n=10)$} & $n$ & 1 & 0 & 3 & 0 & 3 & 0 \\
\hline & mean & 309 & & 185 & & 7060 & \\
\hline & median & & & 185 & & 317 & \\
\hline & $\min$ & & & 75.1 & & 275 & \\
\hline & $\max$ & & & 295 & & 20,500 & \\
\hline & $n>$ RoHS & 0 & 0 & 0 & 0 & 1 & \\
\hline
\end{tabular}

\subsection{Avian PBET results}

237 Concentrations of elements mobilised from eight plastic samples subject to the 120-h PBET are

238 shown in Table 4 along with total concentrations determined by XRF. Note that bioaccessibility (BA)

239 is operationally defined as the percentage of each element released by the PBET relative to the

240 corresponding total concentrations. Mobilised concentrations range from $1 \mathrm{mg} \mathrm{kg}^{-1}$ to almost 600

$241 \mathrm{mg} \mathrm{kg}^{-1}$ (for $\mathrm{Br}$ and $\mathrm{Pb}$ in $\mathrm{PVC}$, respectively), with values of $\mathrm{BA}$ ranging from about $0.1 \%$ for $\mathrm{Cr}$ in a

242 yellow plastic to over $2 \%$ for $\mathrm{Pb}$ in PVC. 
244 Table 4: Concentrations of elements released from eight plastic samples after exposure to a 120-h avian PBET. Also shown are total concentrations in

245 plastics determined by XRF, where detected, and measures of bioaccessibility (BA), defined as the percentage release relative to total concentration. In bold are RoHS exceedances or, denoted by an asterisk, potential exceedances.

\begin{tabular}{|c|c|c|c|c|c|c|c|c|c|c|c|c|c|c|c|}
\hline sample & $\mathrm{Br}, \mathrm{mg} \mathrm{kg}^{-1}$ & $\mathrm{Br}-\mathrm{XRF}, \mathrm{mg} \mathrm{kg}^{-1}$ & $\mathrm{Br}-\mathrm{BA}, \%$ & $\mathrm{Cd}, \mathrm{mg} \mathrm{kg}^{-1}$ & $\mathrm{Cd}-\mathrm{XRF}, \mathrm{mg} \mathrm{kg}^{-1}$ & ${ }^{1} \mathrm{Cd}-\mathrm{BA}, \%$ & $\mathrm{Cr}, \mathrm{mg} \mathrm{kg}^{-1}$ & $\mathrm{Cr}-\mathrm{XRF}, \mathrm{mg} \mathrm{kg}^{-1}$ & $\mathrm{Cr}-\mathrm{BA}, \%$ & $\mathrm{~Pb}, \mathrm{mg} \mathrm{kg}^{-1}$ & ${ }^{-1} \mathrm{~Pb}-\mathrm{XRF}, \mathrm{mg} \mathrm{kg}^{-1}$ & $\mathrm{~Pb}-\mathrm{BA}, \%$ & $\mathrm{Sb}, \mathrm{mg} \mathrm{kg}^{-1}$ & $\mathrm{Sb}-\mathrm{XRF}, \mathrm{mg} \mathrm{kg}^{-1}$ & Sb-BA, \% \\
\hline primary, black & & & & 26.3 & 2080 & 1.27 & & & & & & & & & \\
\hline secondary unknown, black PVC & 1.0 & 146 & 0.68 & & & & & & & 576 & 23,800 & 2.42 & & & \\
\hline secondary unknown, black & 115 & $43,400 *$ & 0.26 & & & & & & & & & & 270 & 12,500 & 2.16 \\
\hline primary, black & & & & 21.4 & 1300 & 1.65 & & & & & & & & & \\
\hline secondary, black & 52.4 & $4100^{*}$ & 1.28 & & & & & & & & & & 57.4 & 1510 & 3.81 \\
\hline secondary, green & 16.0 & $1100 *$ & 1.45 & & & & & & & & & & & & \\
\hline secondary unknown, green & & & & 2.4 & 104 & 2.26 & 2.7 & $2910^{*}$ & 0.09 & & & & & & \\
\hline primary, yellow & & & & & & & 16.3 & $1270^{*}$ & 1.28 & 41.9 & 3620 & 1.16 & & & \\
\hline
\end{tabular}




\section{Discussion}

249 Although the results presented herein were derived from six beaches in one region of southwest

250 England, global commonalities in WEEE regulations, constraints on sorting black plastics and life 251 cycles of plastics (Turner, 2018a; Zheng et al., 2018) suggest that the findings are likely to be more generally applicable to beached litter. Thus, it is evident that waste plastic which is clearly and directly electronic or electrical in nature, either visibly or chemically, is not particularly abundant. This may partly reflect the value of small electrical items compared with food packaging and other waste that is discarded in situ and that there is less incentive to retrieve. WEEE as a composite of plastic, glass and metal, for example, is also much denser than plastics comprised largely of polyolefins that usually characterise beach litter (Massos and Turner, 2017; Karthik et al., 2018), meaning that discarded WEEE, including any disposed of at sea, is unlikely to travel far from its point of origin. In a recent paper, for example, Fortibuoni et al., 2019) observed large items of WEE from scuba trawls in the coastal waters of the Adriatic Sea which were attributed to isolated instances of in situ fly-tipping and illegal dumping. Accordingly, we may assume that WEEE retrieved from two beaches in the present study that was composed of relatively dense PVC cable insulation and that often encased conductive metal wire had been disposed of locally. An association of PVC insulation with high concentrations of $\mathrm{Pb}$ in black cable insulation (but not in white) suggests that such material may be relatively old as heavy metal-based stabilisers have been progressively phased out (VinylPlus, 2014). However, this characteristic alone does not allow discrimination between old material that has been recently discarded and old material that has persisted in the environment.

Of greater significance, and in particular to lower density beached plastic that has the propensity for longer-range transport, is material that has been recycled in whole or in part from WEEE. Given that, apart from as brominated flame retardants, the only other known use of $\mathrm{Br}$ in plastic is a component of the halogenated copper phthalocyanine pigments (Ranta-Korpi et al., 2014), the presence of the element in plastic that is not coloured blue-green and that contains $\mathrm{Cu}$ is a useful proxy for functional EEE or recycled WEEE. Accordingly, we may infer that of the 264 non-EEE black plastic items of litter retrieved from the beach surveys, 93 (or 35\%) have been derived through WEEE recycling. (Note, however, that with detection of $\mathrm{Br}$ constrained to a few $\mathrm{mg} \mathrm{kg}^{-1}$, this figure may represent an underestimate.) Regarding plastics of other colour type, only seven out of 224 items (or $3 \%)$ that are mainly white or grey, appear to contain residual WEEE plastic from recycling based on the criteria above. association and correlation of $\mathrm{Br}$ with $\mathrm{Sb}$. Thus, while $\mathrm{Sb}$ has a number sources and applications in 
plastics, its dominant use is in the form of $\mathrm{Sb}_{2} \mathrm{O}_{3}$ as a flame quenching synergist for organohalide compounds (Grause et al., 2011). In the present study, $\mathrm{Br}$ and Sb were detected together in 23 samples of black plastic across all categories and in two samples of plastic of other colour (note that a relatively high detection limit of $\mathrm{Sb}$ is likely to have precluded identification of further associations). The relationship between $\mathrm{Sb}$ and $\mathrm{Br}$, illustrated in Figure 3, discriminates data according to colour and whether the polymer is PVC-based. Thus, the principal outlier with a Sb content of about 15,000 mg kg${ }^{-1}$ and a Br content of below $30 \mathrm{mg} \mathrm{kg}^{-1}$ is PVC cable insulation where, presumably, $\mathrm{Sb}_{2} \mathrm{O}_{3}$ is used as a synergist for the chlorinated polymer itself, and the two non-black samples are green fragments where both $\mathrm{Br}$ and $\mathrm{Sb}$ are likely to be present as components of coloured pigments. Excluding these three data points $(n=22)$, statistical analyses reveal a Pearson's moment correlation coefficient of $0.993(p<0.001)$ and a gradient and intercept of $\mathrm{Sb}-\mathrm{Br}$ of $0.286 \pm$ $0.013(p<0.001)$ and $203 \pm 127 \mathrm{mg} \mathrm{kg}^{-1}(p=0.003)$, respectively. The gradient of the relationship is comparable to that defining both black plastic non-EEE consumer goods $(0.386)$ and historical and contemporary EEE items (0.342) (Turner, 2018a).

Given these quantitative similarities, and the fact that $\mathrm{Br}$ and $\mathrm{Sb}$ (and often in association with $\mathrm{Cd}$ and/or $\mathrm{Pb}$ ) was observed in samples of black plastic across all categories and of origins related to the consumer (e.g. bottle lids, hair grips and a clothes hanger), marine applications (e.g. fragments of rope, netting and traps) and industry (mainly bio-beads), suggests that the recycling of contaminated WEEE plastic is a heterogeneous and pervasive issue that has been practised for some time. The means by which hazardous chemicals and WEEE plastic are lost in nature and enter the marine environment are illustrated within the more general life cycle of plastics in Figure 4. Thus, through illegal or uncontrolled disposal, WEEE plastic enters the environment directly, while through improper screening and sorting of WEEE according to RoHS criteria and the consequent and incidental recycling of material into consumer goods and industrial and marine plastics, WEEEcontaminated plastic enters the environment from a wide variety of land-based and marine waste sources.

While, overall, the chemical signature of beached plastic is similar to that of contemporary consumer goods (Turner, 2018a), there are some important differences between the two types of plastic. Thus, firstly, beached plastic derived from consumer goods is likely to be older than goods in use and the composition may reflect regulations (or lack of regulations) and practices that were in place historically. Specifically, in the current context, WEEE-contaminated beached plastics are likely to be older and contain a higher proportion of RoHS non-compliant additives or residues compared with contemporary consumer goods where there has been a progressive dilution of older plastic with newer materials through recycling. Secondly, beached plastics contain industrially-derived material 
that is often derived from the direct recycling of WEEE and whose contribution to marine litter may be considerable in some locations (Turner et al., 2019). Thirdly, significant quantities of beached plastics are weathered and fragmented and are associated with a higher surface area and a greater propensity to leach additives than functional consumer goods.

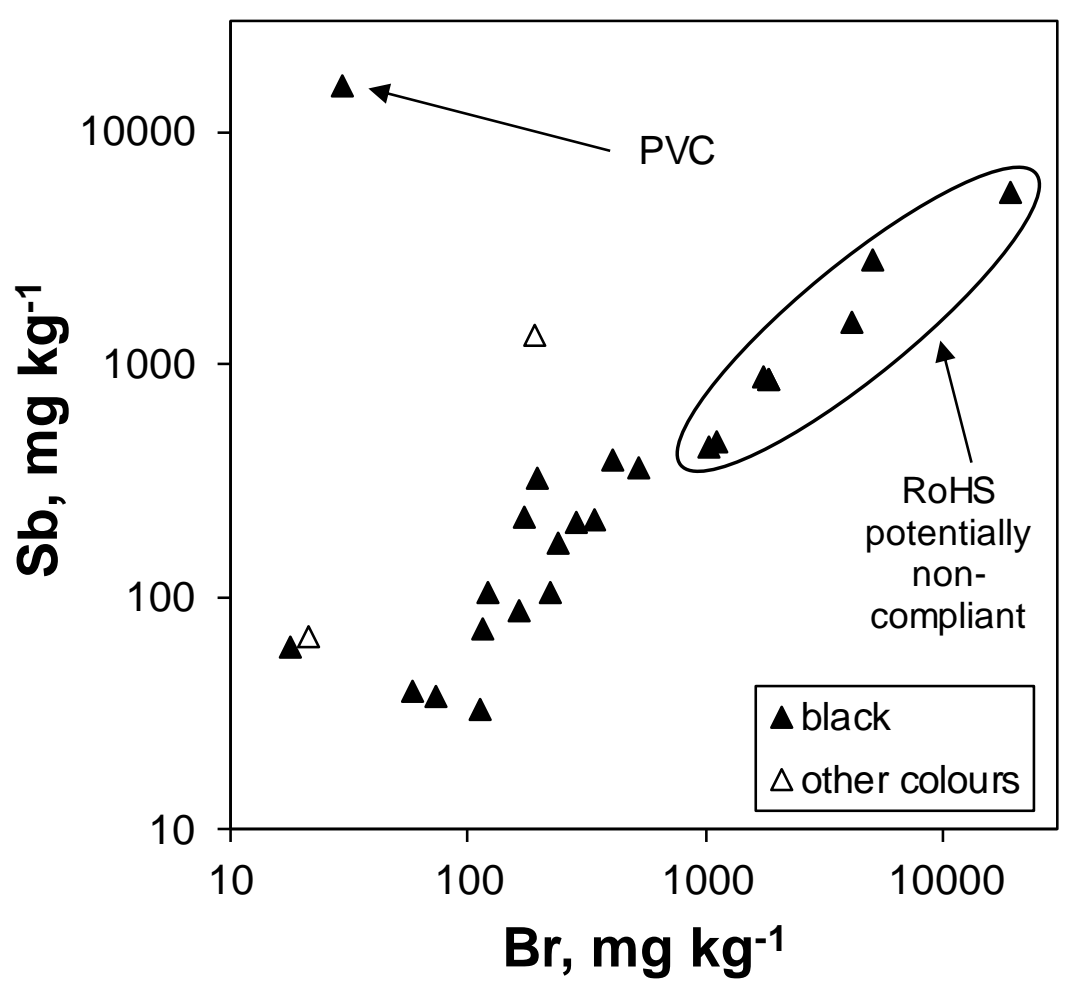

Figure 3: Relationship between concentrations of $\mathrm{Sb}$ and $\mathrm{Br}$ in beached plastics of different colour type. Note the anomalous PVC-based sample of high Sb content and samples that are potentially non-compliant with respect to the RoHS.

Unlike consumer plastics, the presence or concentrations of hazardous chemicals in plastic litter in the marine environment is not regulated and has rarely been monitored. Significantly, the data shown in Tables 2 and 3 reveal that regulatory (RoHS) limits based on potential health and environmental risks arising from components of EEE, including EEE plastic, are breached or potentially breached in about $15 \%$ of black plastics collected in the study. By comparison, $10 \%$ of plastics of other colours exceed RoHS limits, and mainly for $\mathrm{Cd}, \mathrm{Cr}$ and $\mathrm{Pb}$ in secondary fragments where lead chromates and cadmium sulphides were historically used as pigments for colour. Clearly, hazardous chemicals used in or derived from EEE are not expected in marine litter, and pose risks and exposure routes to receptors, including sediment, invertebrates, fish, birds and mammals, that 
are not anticipated nor well-understood. The widespread occurrence of brominated flame retardants in black plastic is a particular concern in this respect because these compounds are synthetic and not contained in the normal diet. Moreover, there is evidence that a high proportion of dark microplastics (including those coloured black) is ingested by various seabirds (Ryan, 1987; Turner et al., 2019), although it is unclear whether such observations are related to plastic selectivity or availability.

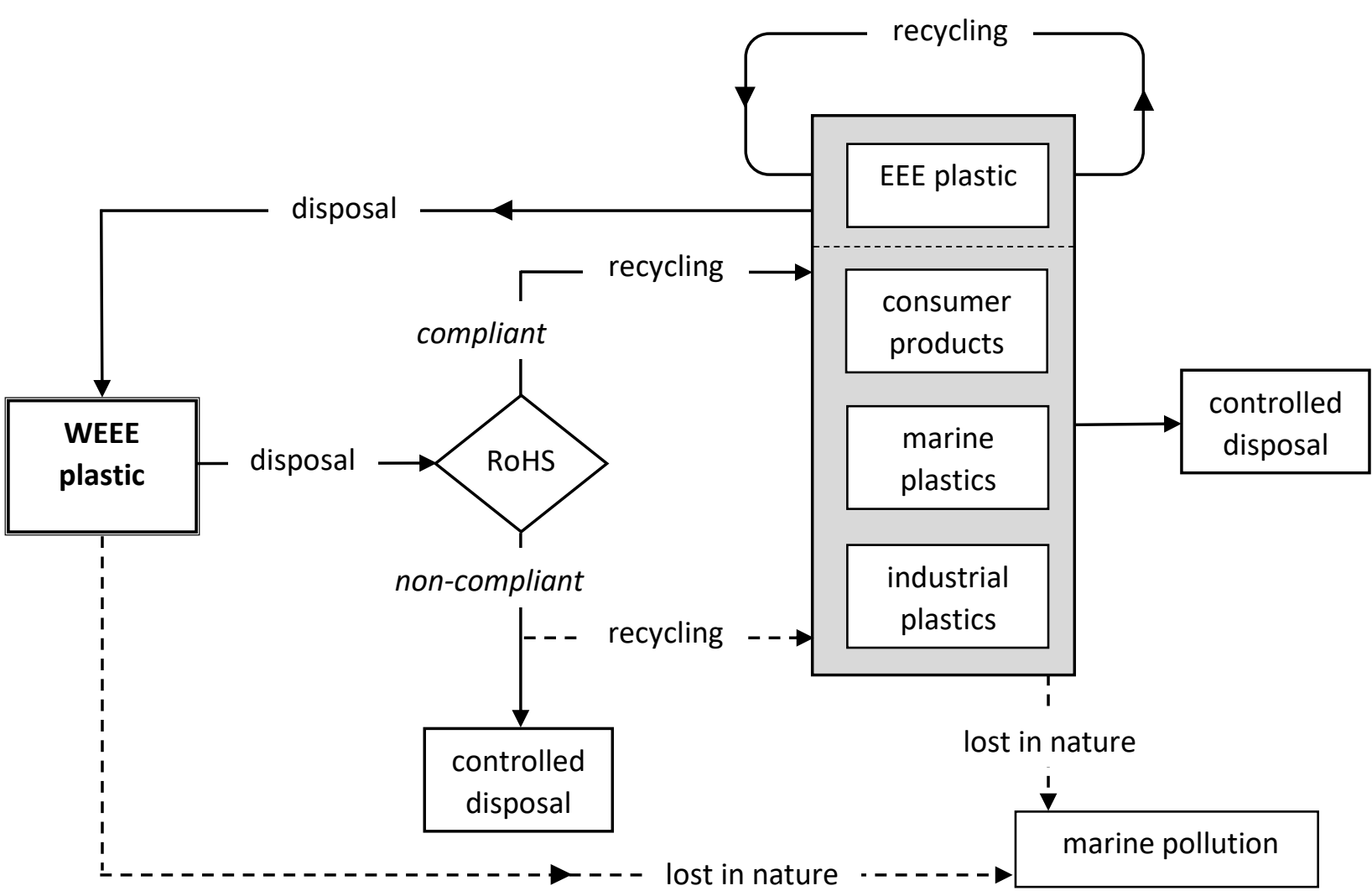

Figure 4: Flow chart showing the life cycle of WEEE plastic and routes of entry into the marine environment. Broken lines denote non-preferred or undesired pathways.

Regarding the five-day avian PBET results reported herein, bioaccessibility (but not necessarily bioavailability) of restricted elements (and including $\mathrm{Sb}$ ) is variable but in the range of about $0.1 \%$ to $2.4 \%$ and which can be greater than $100 \mathrm{mg} \mathrm{kg}^{-1}$ in some cases. By comparison, an alternative avian PBET that includes lipophilic dietary components of Procellariiforms like fish oil has recently been tested on high density polyethylene compounded with decaBDE where it was shown that $40 \%$ of the brominated flame retardant could be mobilised (Tanaka et al., 2015), a mechanism that provided an explanation for the accumulation of specific PBDEs in the tissues of wild sea birds from the North Pacific Ocean. 
Local contamination of the water column by brominated flame retardants and their subsequent bioaccumulation may also result from the slow but continuous diffusive leaching from suspended or deposited plastic debris (Rochman et al., 2014). This effect has been suggested as a means by which certain brominated compounds are accumulated by juvenile yellowtail fish (Seriola lalandi) in the North Pacific Central Gyre, a region remote from any land-based chemical emissions (Gassel et al., 2013). For animals inhabiting or attached to larger pieces of plastic debris, both indirect (leaching) and direct accumulation of hazardous chemicals from the substrate are possible. For example, Jang et al. (2016) showed that mussels rafting on buoyant Styrofoam were able to accumulate hexabromocyclododecane (flame retardant) additives from the underlying plastic, although the precise mechanisms of uptake were not studied.

WEEE plastic is recognised as being potentially hazardous in terms of chemical additives and regulations are in place to minimise their use in new EEE products. However, through improper screening and sorting of WEEE, recyclate derived from this stock, and in particular black plastic, is readily contaminated. This introduces hazardous additives and residues into plastics more generally and where they are not expected, affording a route of chemical exposure to humans and, through pollution, marine wildlife. The impacts of chemicals in plastics that are introduced to the marine environment are not fully understood but are gaining attention, with findings of the present study also raising the case for classifying plastic litter by colour on the basis of origin and potential toxicity.

\section{Acknowledgements}

We thank Claire Wallerstein, Rame Peninsula Beach Care, for assistance and advice on sampling. Drs Alex Taylor and Andrew Fisher (UoP) are acknowledged for technical support throughout. The study was partly funded by a Plymouth Marine Institute HEIF Grant.

\section{References}

BIS, 2011. RoHS Regulations: Government Guidance Notes. Department for Business, Innovation and Skills URN 11/526, 38pp.

BIS, 2015. Packaging (Essential Requirements) Regulations: Government Guidance Notes. Department for Business, Innovation and Skills https://assets.publishing.service.gov.uk/government/uploads/system/uploads/attachment data/file /460891/BIS-15-460-packaging-essential-requirements-regulations-gov-guidance-notes.pdf (accessed 5/19)

Cao, Z.G., Chen, Q.Y., Li, X.X., Zhang, Y.C., Ren, M.H., Sun, L.F., Wang, M.M., Liu, X.T., Yu, G., 2019. The non-negligible environmental risk of recycling halogenated flame retardants associated with plastic regeneration in China. Science of the Total Environment 646, 1090-1096. 
European Parliament and Council of the EU, 1994. Directive 94/62/EC of 20 December 1994 on packaging and packaging waste. Official Journal of the European Union L365.

European Parliament and Council, 2003. Directive 2002/95/EC on the restriction of the use of certain hazardous substances in electrical and electronic equipment. Official Journal of the European Union L37/19.

Fortibuoni, T., Ronchi, F., Macic, V., Mandic, M., Mazziotti, C., Peterlin, M., Prevenios, M., Prvan, M., Somarakis, S., Tutman, P., Varezic, D.B., Virsek, M.K., Vlachogianni, T., Zeri, C., 2019. A harmonized and coordinated assessment of the abundance and composition of seafloor litter in the AdriaticIonian macroregion (Mediterranean Sea). Marine Pollution Bulletin 139, 412-426.

Gallo, F., Fossi, C., Weber, R., Santillo, D., Sousa, J., Ingram, I., Nadal, A., Romano, D., 2018. Marine litter plastics and microplastics and their toxic chemicals components: the need for urgent preventive measures. Environmental Sciences Europe 30, 13 https://doi.org/10.1186/s12302-018$\underline{0139-z}$

Gassel, M., Harwani, S., Park, J.S., Jahn, A., 2013. Detection of nonylphenol and persistent organic pollutants in fish from the North Pacific Central Gyre. Marine Pollution Bulletin 73, 231-242.

Grause, G., Karakita, D., Ishibashi, J., Kameda, T., Bhaskar, T., Yoshioka, Y., 2011. TG-MS investigation of brominated products from the degradation of brominated flame retardants in high-impact polystyrene. Chemosphere 85, 368-373.

Hahladakis, J.N., Velis, C.A., Weber, R., lacovidou, E., Purnell, P., 2018. An overview of chemical additives present in plastics: Migration, release, fate and environmental impact during their use, disposal and recycling. Journal of Hazardous Materials 344, 179-199.

Hermabessiere, L., Dehaut, A., Paul-Pont, I., Lacroix, C., Jezequel, R., Soudant, P., Duflos, G., 2017. Occurrence and effects of plastic additives on marine environments and organisms: A review. Chemosphere 182, 781-793.

Ilankoon, I.M.S.K., Ghorbani, Y., Chong, M.N., Herath, G., Moyo, T., Petersen, J., 2018. E-waste in the international context - A review of trade flows, regulations, hazards, waste management strategies and technologies for value recovery. Waste Management 82, 258-275.

Jang, M., Shim, W.J., Han, G.M., Rani, M., Song, Y.K., Hong, S.H., 2016. Styrofoam debris as a source of hazardous additives for marine organisms. Environmental Science and Technology 50, 4951-4960.

Karthik, R., Roobin, R.S., Purvaja, R., Ganguly, D., Anandavelu, I., Raghuraman,m R., Hariharan, G., Ramakrishna, A., Ramesh, R., 2018. Microplastics long the beaches of southeast coast of India. Science of the Total Environment 645, 1388-1399.

Lithner, D., Larsson, A., Dave, G., 2011. Environmental and health hazard ranking and assessment of plastic polymers based on chemical composition. Science of the Total Environment 409, 3309-3324.

Massos, A., Turner, A., 2017. Cadmium, lead and bromine in beached microplastics. Environmental Pollution 227, 139-145.

Ranta-Korpi, M., Konttinen, J., Saarimaa, A., Rodriguez, M., 2014. Ash forming elements in plastics and rubbers. VTT Technical Research Centre of Finland, Espoo, Finland, 131pp. 
Rochman, C.M., Lewison, R.L., Eriksen, M., Allen, H., Cook, A.M., Teh, S.J., 2014. Polybrominated diphenyl ethers (PBDEs) in fish tissue may be an indicator of plastic contamination in marine habitats. Science of the Total Environment 476, 622-633.

Rozenstein, O., Puckrin, E., Adamowski, J., 2017. Development of a new approach based on midwave infrared spectroscopy for post-consumer black plastic waste sorting in the recycling industry. Waste Management 68, 38-44.

Ryan, P. G., 1987. The incidence and characteristics of plastic particles ingested by seabirds. Marine Environmental Research 23, 175-206.

Tanaka, K., Takada, H., Yamashita, R., Mizukawa, K., Fukuwaka, M.A., Watanuki, Y., 2015. Facilitated leaching of additive-derived PBDEs from plastic by seabirds' stomach oil and accumulation in tissues. Environmental Science and Technology 49, 11799-11807.

Turner, A., 2018a. Black plastics: linear and circular economies, hazardous additives and marine pollution. Environment International 117, 308-318.

Turner, A., 2018b. Mobilisation kinetics of hazardous elements in marine plastics subject to an avian physiologically-based extraction test. Environmental Pollution 236, 1020-1026.

Turner, A., Filella, M., 2017. Bromine in plastic consumer products - Evidence for the widespread recycling of electronic waste. Science of the Total Environment 601-602, 374-379.

Turner, A., Wallerstein, C, Arnold, R., 2019. Identification, origin and characteristics of bio-bead microplastics from beaches in western Europe. Science of the Total Environment 664, 938-947.

VinylPlus, 2014. The European PVC industry's experience in replacing lead and cadmium-based stabilisers https://www.stabilisers.eu/wp-content/uploads/2015/11/VinylPlus Contribution-

\section{Cefic Eu-Industry.pdf}

Wäger, P.A., Schluep, M., Müller, E., Gloor, R., 2012. RoHS regulated substances in mixed plastics from waste electrical and electronic equipment. Environmental Science and Technology 46, 628-635.

Zheng, Y., Bai, J., Xu, J., Li, X., Zhang, Y., 2018. A discrimination model in waste plastics sorting using NIR hyperspectral imaging system. Waste Management 72, 87-98. 